\title{
Crustal variability along the rifted/sheared East African margin: a review
}

\author{
Maren Vormann ${ }^{1}$ (D) Wilfried Jokat ${ }^{1,2}$ (D \\ Received: 4 September 2020 / Accepted: 14 March 2021 / Published online: 8 April 2021 \\ (C) The Author(s) 2021
}

\begin{abstract}
The East African margin between the Somali Basin in the north and the Natal Basin in the south formed as a result of the Jurassic/ Cretaceous dispersal of Gondwana. While the initial movements between East and West Gondwana left (oblique) rifted margins behind, the subsequent southward drift of East Gondwana from 157 Ma onwards created a major shear zone, the Davie Fracture Zone (DFZ), along East Africa. To document the structural variability of the DFZ, several deep seismic lines were acquired off northern Mozambique. The profiles clearly indicate the structural changes along the shear zone from an elevated continental block in the south $\left(14^{\circ}-20^{\circ} \mathrm{S}\right)$ to non-elevated basement covered by up to $6-\mathrm{km}$-thick sediments in the north $\left(9^{\circ}-13^{\circ} \mathrm{S}\right)$. Here, we compile the geological/geophysical knowledge of five profiles along East Africa and interpret them in the context of one of the latest kinematic reconstructions. A pre-rift position of the detached continental sliver of the Davie Ridge between Tanzania/ Kenya and southeastern Madagascar fits to this kinematic reconstruction without general changes of the rotation poles.
\end{abstract}

Keywords Davie Ridge · Davie Fracture Zone · Gondwana breakup · Kinematic reconstruction · Continental fragment

\section{Introduction}

The breakup of Gondwana commenced around $182 \mathrm{Ma}$ ago with massive emplacement of flood basalts and subsequent rifting in the Mozambique Basin (Müller and Jokat 2019). No such massive volcanism has been reported further north

This article is part of the Topical Collection on Coastal and marine geology in Southern Africa: alluvial to abyssal and everything in between

\section{Highlights}

-The northern Mozambican margin is an atypical transform margin.

-The continent ocean transition does not always coincide with the Davie Fracture Zone.

- The Davie Ridge is separated into a sedimentary northern and a continental southern part.

-A refined kinematic reconstruction, which includes the continental fragment of the Davie Ridge, is discussed.

Maren Vormann

Maren.Vormann@awi.de

1 Alfred Wegener Institute, Helmholtz Centre for Marine and Polar Research, Am Handelshafen 12, Bremerhaven, Germany

2 University of Bremen, Department of Geosciences, Klagenfurter Strasse 4, Bremen, Germany along the northern Mozambican, Tanzanian, Kenyan and Somali margins (Mortimer et al. 2020). Here, the rifting and subsequent separation of Madagascar from East Africa were mainly magma poor. A variety of reconstructions present Madagascar as part of East Gondwana (Antarctica, India, Australia) (Heirtzler and Burroughs 1971; Reeves et al. 2002, 2016; Jokat et al. 2003; Leinweber and Jokat 2012; Reeves 2014; Davis et al. 2016; Phethean et al. 2016; TuckMartin et al. 2018; Müller and Jokat 2019). In these reconstructions, Madagascar has various pre-rift positions and rotations north of Kenya and Tanzania, which were part of West Gondwana (Africa, South America). The initial direction of rifting and drifting of East from West Gondwana between 182 and $157 \mathrm{Ma}$ (GTS2012, Ogg 2012) was mainly perpendicular to the present-day coastline off central Mozambique and Somalia, and oblique to the coasts of northern Mozambique, Tanzania and Kenya (Müller and Jokat 2019). This was the case until approximately $157 \mathrm{Ma}$ (M26r, Müller and Jokat 2019). Then, between 157 and $144 \mathrm{Ma}$ (M26r-M28n), the spreading direction, in present-day African coordinates, between East and West Gondwana changed to N-S (Phethean et al. 2016; Müller and Jokat 2019). Initial movements between Greater India (India and Madagascar) and East Antarctica began about $136 \mathrm{Ma}$ as well as the separation of Australia from East Gondwana (M14r, Reeves 2018). 
Madagascar, whilst still connected to India, reached its final position with respect to Africa at some point in Early Cretaceous times (M9n-M1n, Eagles and König 2008; Davis et al. 2016; Tuck-Martin et al. 2018; Müller and Jokat 2019). The latter movement created a large fracture zone and/or transform system in the Somali Basin and the Mozambique Channel, known as the Davie Fracture Zone (DFZ) or Davie Transform System (DTS) (Bunce and Molnar 1977; Davis et al. 2016; Sinha et al. 2019).

Today, the Mozambique Channel separates Madagascar from the African continent between $12^{\circ}$ and $25^{\circ} \mathrm{S}$. Here, the most prominent topographic feature is the Davie Ridge (DR) running parallel to the southeastern branch of the East African Rift System along the DFZ (Chorowicz 2005). Mascle et al. (1987) proposed that the DR consists of three different parts: a northern part between $9^{\circ}$ and $13^{\circ} \mathrm{S}$ with a steep western flank, a middle section of numerous seamounts between $13^{\circ}$ and $17^{\circ} \mathrm{S}$ and a southern part between $17^{\circ}$ and $20^{\circ} \mathrm{S}$ in the Mozambique Basin. Recent investigations classified the southern and middle parts of the DR to have a continental origin, while the northern part is a sedimentary build-up (Franke et al. 2015; Klimke et al. 2016; Vormann et al. 2020; Vormann and Jokat in review). This is supported by dredge samples analysed by Bassias (1992). At the transition at $13^{\circ} \mathrm{S}$, the DR is not physiographically present, but slightly further south, it seems to turn towards the continent. Several sedimentary basins are observed along the western flank of the DR, such as the Kerimbas Basin in the north and the Lacerda Basin in the south. Along the margin of East Africa, a gravity low is observed, which is mostly connected with the transform margin (Mascle et al. 1987). Regional kinematic models for the East African margin suffer from the poor knowledge of the location and shape of the transition between continental and oceanic crust, especially along northern Mozambique, which might be used to better constrain the movement of Madagascar. In the absence of such knowledge, questions remain: Did Madagascar's drift away from Africa follow a path close to the present-day African coast, or even inland of it? Does the topographic expression of the DFZ reliably indicate its crustal affinity and, if yes, how? Can continental crust be confirmed by seismic refraction data under the DR? If so, where was the DR continental sliver situated before Gondwana breakup? How does the crustal fabric change in comparison with that of the rifted margin of central Mozambique?

These questions have partly been addressed in several publications. Here, we review their findings by displaying the five crustal transects in a consistent way. For this, we focus on the crustal variability of the DR along central and northern Mozambique and compare the results to knowledge gained from other geophysical data.

\section{Crustal structure off Northern Mozambique-similarities/differences}

In 2007 and 2014, seismic refraction data were acquired in the Mozambique Channel during three scientific expeditions (AISTEK II, MOCOM and PAGE-FOUR cruises). The five seismic refraction lines reviewed here all cross the DFZ. Four of them are east-west oriented and the fifth runs NNE-SSW. Together, they reveal crustal information along more than $1400 \mathrm{~km}$ of the East African coast between $11^{\circ} \mathrm{S}$ and $20^{\circ} \mathrm{S}$ (Figs. 1 and 2; Leinweber et al. 2013; Müller and Jokat 2017; Vormann et al. 2020; Vormann and Jokat in review). The profiles are labelled A to E from north to south.

In all seismic refraction profiles (Fig. 2), we observe a sedimentary cover up to $6 \mathrm{~km}$ thick, with sedimentary velocities reaching values of up to $4.7 \mathrm{~km} / \mathrm{s}$ just above the acoustic basement, which are typical for this region (Lort et al. 1979; Müller et al. 2016; Müller and Jokat 2017). Crustal velocities along our five lines start at around $5.5 \mathrm{~km} / \mathrm{s}$ in the southern part, are around $5.1 \mathrm{~km} / \mathrm{s}$ in the north and increase up to 7.0 $\mathrm{km} / \mathrm{s}$ in the lower crust (Leinweber et al. 2013; Müller and Jokat 2017; Vormann et al. 2020; Vormann and Jokat in review), as is typical for the Central Mozambican margin (Leinweber et al. 2013; Müller et al. 2016; Müller and Jokat 2017).

Along the 182-km-long northern profile A (AWI20140150, Vormann and Jokat in review), the DR forms the eastern margin of the Kerimbas Basin (KB, Fig. 2). Some basement elevations are observed beneath the Kerimbas Basin, but there is no distinct basement topography beneath the DR. No steep deepening of the Mohorovičić discontinuity (Moho) is visible in the west of the DR (Fig. 2). The velocity gradient matches to an interpretation of highly stretched continental crust (Christensen and Mooney 1995) and intruded continental crust (Sibuet et al. 2016), both of which are typical for a continent-ocean transition zone (COT) (Vormann and Jokat in review). Here, the DFZ is located below the Kerimbas Basin. East of the DR, the basement and Moho are both flat-lying. The crustal thickness $(7 \mathrm{~km})$ and the velocity-depth distribution match those of the old oceanic crust as observed south of this line (White et al. 1992; Leinweber et al. 2013; Müller et al. 2016; Vormann et al. 2020).

Along the second profile, B, at $13^{\circ} \mathrm{S}$ (AWI-20140130, Vormann and Jokat in review), the seafloor and basement have no elevation in the area of the expected DR (Fig. 2). The western end of the profile represents the COT and shows a steep decrease in crustal thickness seawards, as constrained by gravity modelling. The velocity gradient within the COT matches that of stretched continental crust (Christensen and Mooney 1995). The onset of up to $6.5-\mathrm{km}$-thick oceanic crust lies to the west of a crustal bulge (CB, Fig. 2), a rather unusual structure that is probably connected to underplated material feeding 


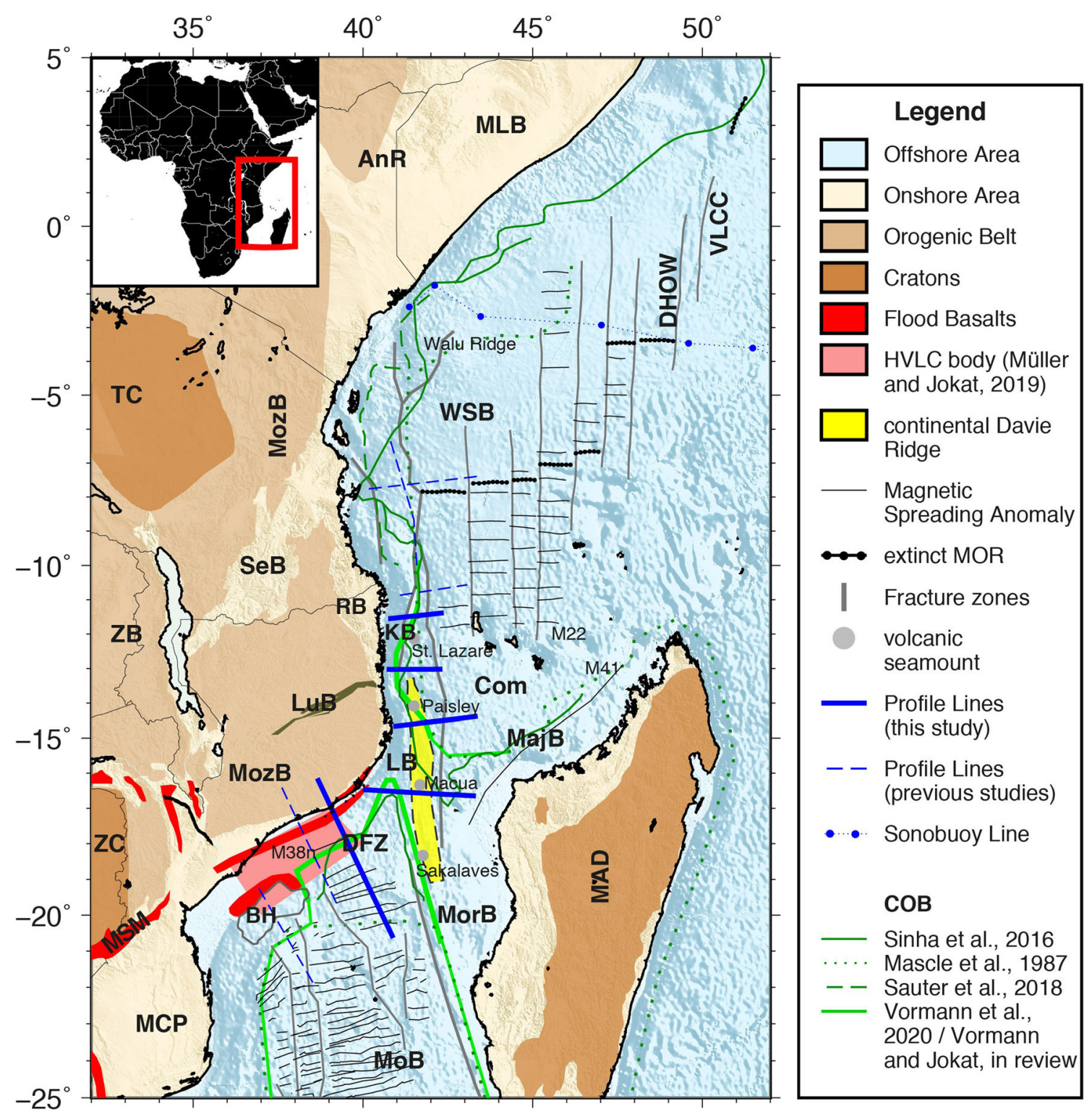

Fig. 1 Overview of the geologic structures in East Africa, the earthquake distribution and the postulated minor plates according to Stamps et al. (2008). Abbreviations: Anza Rift (AnR), Beira High (BH), Comores (Com), Davie Fracture Zone (DFZ), Kerimbas Basin (KB), Lacerda Basin (LB), Lurio Belt (LuB), Madagascar (MAD), Mandava-Lugh
Basin (MLB), Majunga Basin (MajB), Mozambique Basin (MoB), Mozambique Coastal Plains (MCP), Morondava Basin (MorB), Mozambique Belt (MozB), Monotake-Sabi-Monokline (MSM), Rovuma Basin (RB), Selous Basin (SeB), West Somali Basin (WSB), Tanzania Craton (TC), Zambesi Belt (ZB), Zambesi Craton (ZC) neo-volcanism at Paisley Seamount (Vormann and Jokat in review). The true extent of the observed underplating cannot be determined from a single profile. Thus, its regional relevance remains speculative. Recent volcanism is also observed further south at the Sakalaves seamount (Courgeon et al. 2018). The DFZ is interpreted to be located over the area of underplated material and to be situated in oceanic crust.

Further south, profile C at $14.5^{\circ} \mathrm{S}$ (AWI-20140100, Vormann et al. 2020) reveals the DR as a basement elevation covered by thin $(2 \mathrm{~km})$ sediments. Close to the Mozambican coast in the west, the data show a crustal thickness of $15 \mathrm{~km}$, which continuously decreases towards the DR. The DFZ is suggested to lie east of DR, in thinned (5.5 km thick) oceanic crust. The presence of oceanic crust $(7.1 \mathrm{~km})$ is well characterized by its typical thickness and velocity gradient (White et al. 1992; Vormann et al. 2020).

The three northern profiles (A-C) do not reveal crustal characteristics that would be typical of a purely sheared margin, such as a steep decrease in crustal thickness and/ or a narrow COT (Bird 2001). The margin, in contrast, shows a variable and complex crustal structure, with different COT geometries and a fracture zone that is partially located in oceanic crust. This may be explained by an initially oblique phase of separation of the northern 
Fig. 2 Compilation of the interpretations of 5 seismic refraction profiles along the northern Mozambican margin. Profile A: $182 \mathrm{~km}$ with 20 OBS/ OBH (Vormann and Jokat., in review), profile B: $178 \mathrm{~km}$ with $20 \mathrm{OBS} / \mathrm{OBH}$ (Vormann and Jokat., in review), profile C: $270 \mathrm{~km}$ with $24 \mathrm{OBS} / \mathrm{OBH}$ (Vormann et al. 2020), profile D: $356 \mathrm{~km}$ with $22 \mathrm{OBS} / \mathrm{OBH}$ (Vormann et al. 2020), profile E: $500 \mathrm{~km}$ with 35 OBS (Leinweber et al. 2013; Müller and Jokat 2017). Bathymetry is shown in blue. Abbreviations are: CBcrustal bulge (underplated material), cont-continental crust, COTcontinent ocean transition zone, DR-Davie Ridge, HVLC-high velocity lower crust, KB-

Kerimbas Basin, oc-oceanic crust

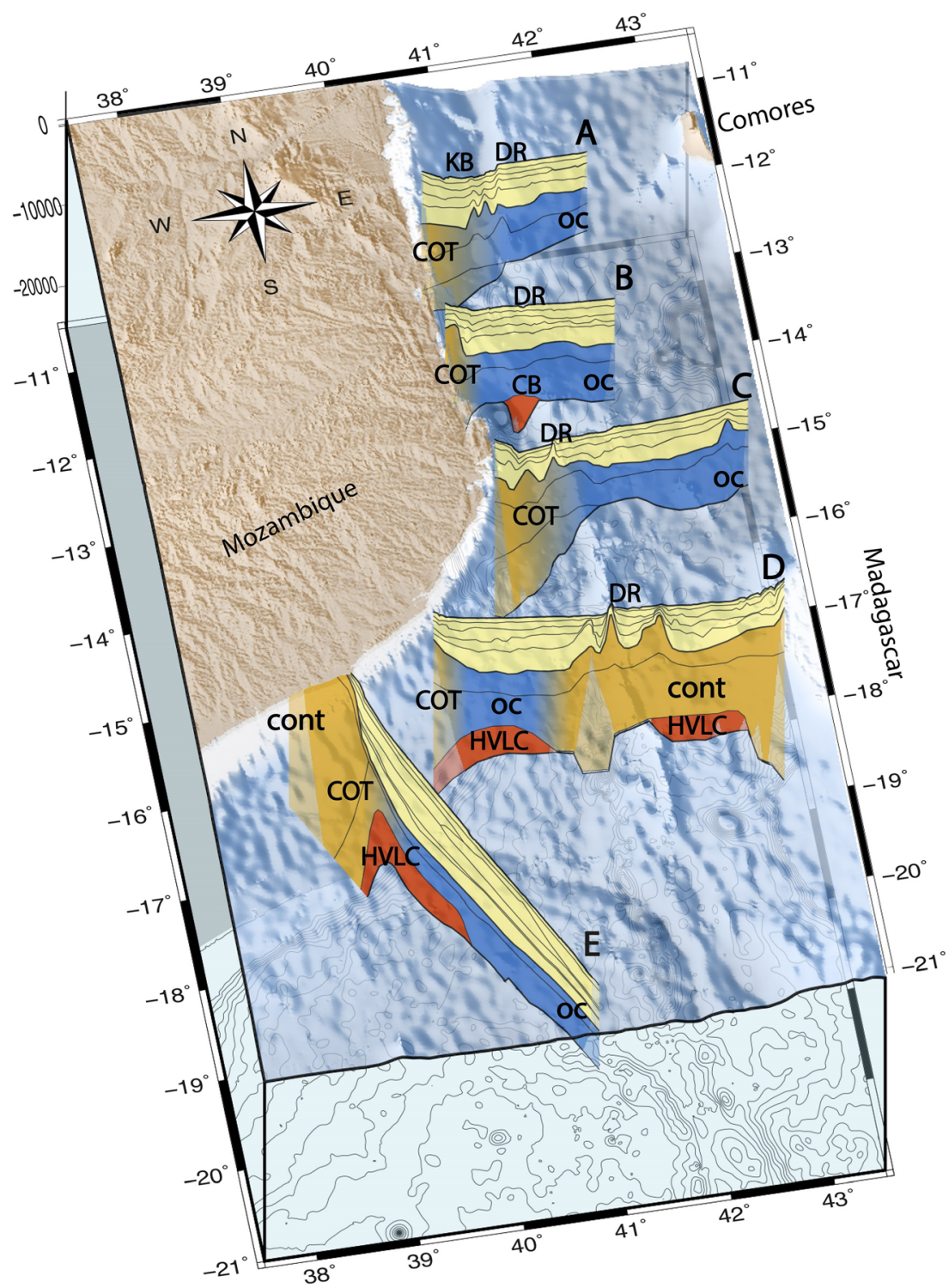

Mozambican, Tanzanian, and Kenyan margins from their conjugates during the Jurassic. NNW-SSE-oriented extension of continental crust and formation of early oceanic crust preceded a change in the direction of divergence between East and West Gondwana to N-S between 157 and $144 \mathrm{Ma}$, leading to the formation of a major shear zone, the Davie Fracture Zone (DFZ). This evolution is responsible for the present-day crustal variability along the East African margins.

The fourth profile, $\mathrm{D}$, at $16.5^{\circ} \mathrm{S}$ shows strong crustal variations. At its western part off Mozambique (AWI20140050, Vormann et al. 2020), a thin body of high velocity lower crust (HVLC) is observed beneath the COT (Fig. 2). Eastwards, only a small corridor of oceanic crust $(70 \mathrm{~km})$ is found before the western margin of the DR for which a continental origin is encountered. In the centre of the line, the DFZ is observed to coincide with the DR and two additional buried ridges. The velocity distribution is similar to that of stretched continental crust, as observed in continental fragments such as the Beira High (Müller et al. 2016). The crustal thickness and velocity distribution further east do not support the presence of oceanic crust towards the northwestern Madagascan margin. Instead, the crust is interpreted as stretched continental crust that may be underlain by a thin HVLC (120 km wide, $2.5 \mathrm{~km}$ thick), consistent with the presence of magmatic intrusions in the sediments off Madagascar (Klimke et al. 2016).

The southernmost profile, E (AWI-20070201, Leinweber et al. 2013, Müller and Jokat 2017), between $16^{\circ}$ and $20^{\circ} \mathrm{S}$, is oriented NNW. It describes the transition from Jurassic oceanic crust off Central Mozambique to the onshore continental crust of the Mozambique Belt. This profile shows a $220-\mathrm{km}$ wide HVLC body beneath the COT (Müller and Jokat 2017) 
with a mean thickness of about $5 \mathrm{~km}$. Oceanic crust appears only $100 \mathrm{~km}$ off the coast, where it is constrained by linear magnetic reversal anomalies interpreted as isochrons in the sequence starting at M38n.2n (Müller and Jokat 2017, 2019).

The two southern deep seismic sounding lines $(D+E)$ image a typical volcanic rifted margin with a HVLC body and seaward dipping reflectors (SDRs) within the COT (Leinweber et al. 2013; Müller and Jokat 2017; Vormann et al. 2020). Onshore up to $15.5^{\circ} \mathrm{S}$, the landward limit of Jurassic rifted crust is marked by intrusions of middle Jurassic age in the coastal areas (Müller and Jokat 2017). The northern terminations of the intrusions and the HVLC body coincide.

\section{Consequences for geological interpretations off Mozambique}

The velocity-depth models described in the previous chapter support proposals to split the DR into two structurally different parts (Mascle et al. 1987; Klimke and Franke 2016; Klimke et al. 2018; Vormann et al. 2020; Vormann and Jokat in review). In the northern part of the DR, between $9^{\circ} \mathrm{S}$ and $13^{\circ} \mathrm{S}$, we observe no basement elevation in the seismic data (Fig. 2, profiles A and B). The DR on profile A is merely the eastern rift shoulder of the Kerimbas Basin, whereas on profile $\mathrm{B}$, no elevation is observed at all. The middle part of the DR is described by profiles $C$ and D: on both profiles, the DR is situated in stretched continental crust. On profile $\mathrm{C}$, the DR is located within the COT, as characterised by $10 \mathrm{~km}$ thick crust. Further south (profile D), the crust beneath the DR is up to $15 \mathrm{~km}$ thick and has nearly no sedimentary cover (Fig. 2). Its velocity structure fits well to that of stretched continental crust (Christensen and Mooney 1995), with slightly lower velocities in the upper mantle (Vormann et al. 2020). The analysis of seismic reflection data (Mougenot et al. 1986; Klimke and Franke 2016; Klimke et al. 2016, 2018) also supports the interpretation of the southern part of the DR as a continental fragment. Our data confirm older interpretations made on the basis of continental rock samples dredged between $14^{\circ}$ and $16^{\circ} \mathrm{S}$ along the flanks of the DR (Virlogeux 1987; Bassias 1992). Geochemical analyses of the dredge samples indicate strong similarities with Tanzanian and Madagascan sediments (LeClaire et al. 1989). The southernmost part $\left(17-20^{\circ} \mathrm{S}\right)$ of the DR was not investigated by seismic refraction data, but previous gravimetric and seismic reflection studies (Mougenot et al. 1986; Klimke et al. 2018) as well as dredged rocks (Virlogeux 1987; LeClaire et al. 1989; Bassias and Leclaire 1990; Bassias 1992) also strongly support a continental origin. The outline of the presumed continental part of the DR is illustrated in Figs. 1 and 3 (126 Ma).

The COT and the onset of oceanic crust were defined on the basis of structural changes in the seismic refraction profiles, such as a reduced crustal thickness, changes in the mantle density and seismic velocity changes in the crust. The western boundary of the COT to normal continental crust was not sampled by the experiment, since the profiles could not be extended onshore for political reasons (Fig. 2). The prominent gravity low along the northern Mozambican margin was interpreted by several studies to mark the continent-ocean boundary. Our study shows that this gravity low is mainly caused by variations in composition within the COT. However, there are exceptions where the gravity low does not coincide with the COT. In the north along profiles A and $\mathrm{C}$, the COT correlates with the prominent gravity low having values of $90 \mathrm{mGal}$ and $110 \mathrm{mGal}$. On profile $\mathrm{B}$, in contrast, the overall gravity variation is very small (less than $40 \mathrm{mGal}$ ), and the gravity low in the middle of the profile is related to the underplated material added to the oceanic crust. Thus, the COT cannot be determined by gravity. Along the southern profiles D and E their COT lies directly next to the Mozambican coast and coincides with a positive gravity anomaly, which is typical of a rifted margin. In summary, the pronounced negative gravity anomaly cannot explicity be interpreted marking either the COT nor the continentocean boundary.

\section{Refined(?) kinematic model}

The detached continental sliver of the southern DR is not included in any existing kinematic reconstruction. In this section, we do this for the first time. For the kinematic reconstruction, we used the software GPlates (Müller et al. 2018) to fit the small continental fragment of DR between southern Madagascar and the Kenya/Tanzania coastline on the basis of their previously identified similar geologic properties (LeClaire et al. 1989; Bassias 1992). The rotation parameters for the surrounding plates are taken from Müller and Jokat (2019), who based their model on the interpretation of the most extensive marine magnetic data set in the region. The DR is fitted to the straight, steep, south-western shelf of present-day Madagascar in the southern Morondawa Basin (Fig. 1), whose $\sim 800 \mathrm{~km}$ length fits that of the continental fragment. So located, Fig. 3 (182 Ma) shows the DR in a pre-breakup (182 Ma) position prolonged to the northern Rovuma Basin and adjacent to the southern Morondawa Basin. According to our adapted model, the DR is placed northwards of the Gunnerus Ridge, a feature off East Antarctica, which is located at 182 Ma between northern Mozambique and Sri Lanka (Fig. 3 (182 Ma)) (Leitchenkov et al. 2008). Northern Madagascar fits close to the Somali and Kenyan shores (Leinweber and Jokat 2012; Davis et al. 2016; Phethean et al. 2016; Reeves 2018; Tuck-Martin et al. 2018; Müller and Jokat 2019; Sinha et al. 2019). 


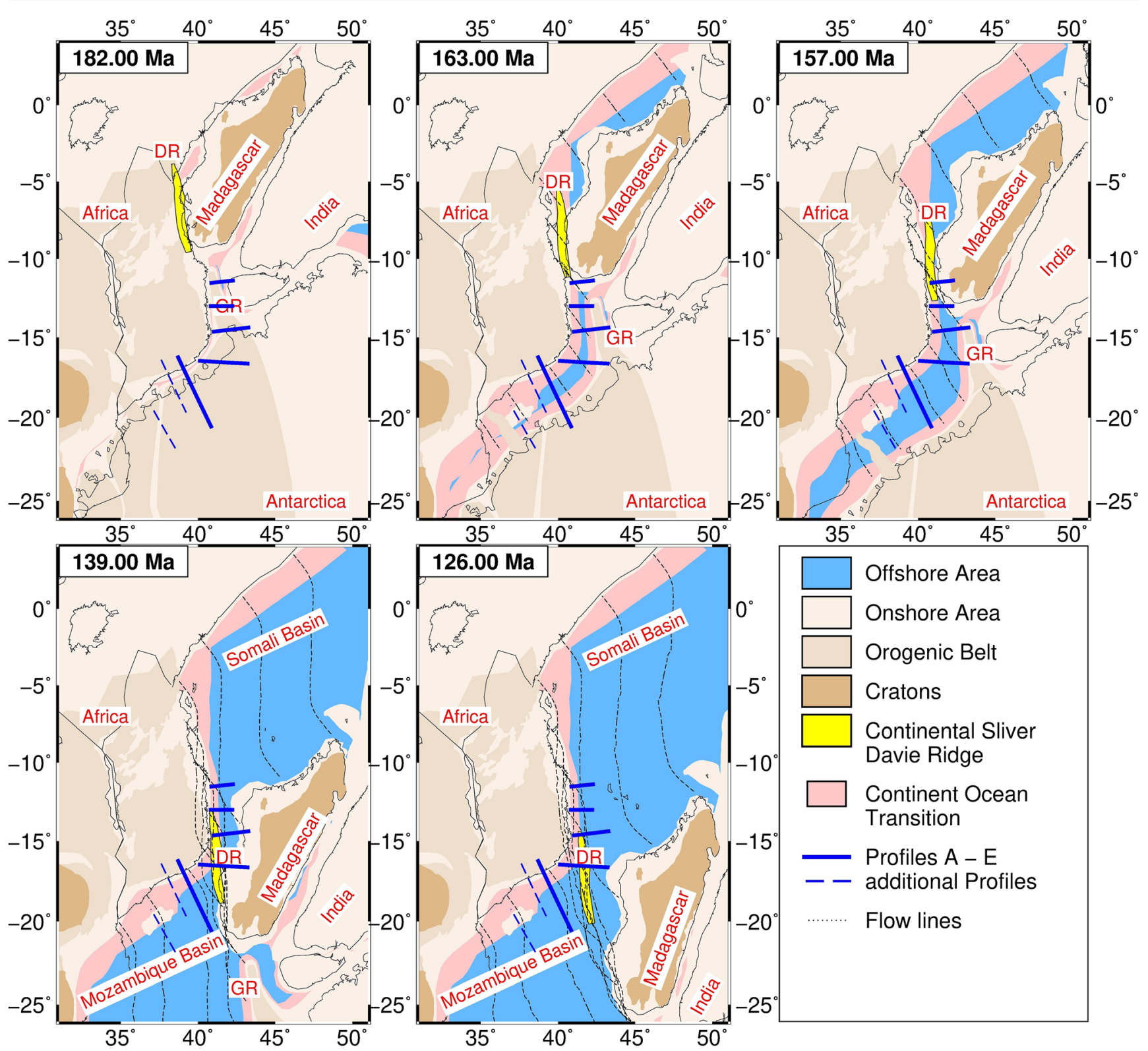

Fig. 3 Kinematic reconstruction of the southern, continental Davie Ridge (DR, yellow) with respect to Africa. The blue lines show the location of the five seismic refraction lines. Rotation poles are taken from Müller and Jokat (2019)

In our reconstruction, the $\mathrm{DR}$ is primarily connected to East Gondwana. According to the Müller and Jokat (2019) model, the initial plate divergence direction was perpendicular to the present-day coastlines of central Mozambique and Somalia. At these margins, a volcanic rifted margin evolved as described by Müller and Jokat (2019). During this oblique phase of East Africa, we propose with the refined model that continental stretching and then accretion of oceanic crust mainly took place between Africa and the DR, and only minor stretching between DR and Madagascar as part of East Gondwana (Fig. 3; 163 Ma, 157 Ma). After Basile (2015), oblique rifting can produce variable geometries in a COT, especially when imaged along profiles that are not aligned parallel to the direction of plate divergence. Between 157 and $144 \mathrm{Ma}$, the orientation of plate motion changed to NS (Müller and Jokat 2019). In our refined reconstruction, the continental DR fragment remained part of East Gondwana during this change (Fig. 3; $157 \mathrm{Ma}, 139 \mathrm{Ma}$ ), with a transform margin located at what is now its western edge. Most of the DFZ, however, then developed in transitional and oceanic crust that had formed during the first phase of continental breakup. Consequently, the preexisting pull-apart sedimentary basins and earliest oceanic crust of the East African margin were deformed/ overprinted. In this model, the DR reached its final 
position with respect to East Africa between 140 and $137 \mathrm{Ma}$ (Fig. 3, $139 \mathrm{Ma}$ ). At this time, Reeves (2018) reports initial movements between India/Madagascar and Antarctica. Davis et al. (2016) state that until $135 \mathrm{Ma}$, East Gondwana rotated as a single cohesive unit, whereas Müller and Jokat (2019) present independent rotation poles for Madagascar and Antarctica from $139 \mathrm{Ma}$ These events possibly led to a change of the transform margin from the western to the eastern side of the DR. Anyhow, the described complex spreading pattern of East Gondwana detached a continental sliver, the southern continental DR, from Madagascar to become part of the African plate. Around $126 \mathrm{Ma}$ (Fig. 3), when spreading ceased in the Somali Basin, Madagascar reached its final position with respect to Africa and became part of the African plate.

This scenario explains the findings along the northern Mozambican margin and the DR, such as the narrow rifted margin on profiles $\mathrm{B}$ and $\mathrm{C}$, the wide DFZ partly in oceanic crust and the complex crustal structure of profile $\mathrm{A}$, and the volcanic rifted margins imaged along profiles $\mathrm{D}$ and $\mathrm{E}$.

\section{Conclusion}

The existence of a simple transform margin at the northern Mozambican coast is not supported by the deep seismic data reviewed in this contribution. The geological evolution is more complex. Large parts of profiles $\mathrm{C}$ and $\mathrm{B}$ represent oceanic crust and the DFZ is located in oceanic crust (Vormann et al. 2020; Vormann and Jokat in review). Both profiles show a wider COT (> $50 \mathrm{~km}$ (B) resp. $100 \mathrm{~km}(\mathrm{C})$ ) than would be expected for a sheared margin (Bird 2001). Further north, profile A has an even broader COT of at least $100 \mathrm{~km}$ beneath the Kerimbas Basin (Figs. 1 and 2) and does not show a sharp decrease of the Moho depth. This hints to a complex opening history for the northern Mozambican margin and probably the Somali Basin. In contrast, the southern profiles (D and E) show clear indications of the presence of a normal rifted margin.

The margin, including the detached continental sliver forming the southern DR, evolved after an initial oblique rifting period and was then overprinted by the southward movement of East Gondwana. North of $12^{\circ} \mathrm{S}$, the Mozambican Margin cannot be classified as a simple transform margin. Here, we assume that the Kerimbas and Rovuma basins are strongly influenced by the initial (oblique) rifting and movement of the DR during the dispersal of Gondwana.

Consequently, we fitted the continental sliver of the DR into a kinematic reconstruction between southwestern Madagascar and Tanzania/Kenya. During initial rifting and subsequent southward movement until $139 \mathrm{Ma}$, the continental DR remained mainly connected to East Gondwana to reach its final position relative to Africa. In our reconstruction, around $139 \mathrm{Ma}$, the fracture zone shifted to the eastern side of the DR where it remained until the cessation of spreading in the Somali Basin around $126 \mathrm{Ma}$.

Acknowledgements This project was founded through a grant by the German Federal Ministry of Education and research (BMBF 03G0230A, 03G0231A) and AWI internal funding. We thank Graeme Eagles for proof reading the manuscript.

Author contribution Maren Vormann: methodology, investigation, writing-original draft, writing-review and editing, visualization. Wilfried Jokat: conceptualization, investigation, writing-review and editing, project administration, funding acquisition

Funding Open Access funding enabled and organized by Projekt DEAL. German Federal Ministry of Education and research (BMBF 03G0230A, 03G0231A) AWI (Alfred Wegener Institute) internal funding.

Availability of data and material The authors have no permission to share the data.

Code availability Gplates: https://www.gplates.org/.

\section{Declarations}

Conflict of interests The authors declare no competing interests.

Open Access This article is licensed under a Creative Commons Attribution 4.0 International License, which permits use, sharing, adaptation, distribution and reproduction in any medium or format, as long as you give appropriate credit to the original author(s) and the source, provide a link to the Creative Commons licence, and indicate if changes were made. The images or other third party material in this article are included in the article's Creative Commons licence, unless indicated otherwise in a credit line to the material. If material is not included in the article's Creative Commons licence and your intended use is not permitted by statutory regulation or exceeds the permitted use, you will need to obtain permission directly from the copyright holder. To view a copy of this licence, visit http://creativecommons.org/licenses/by/4.0/.

\section{References}

Bassias Y (1992) Petrological and geochemical investigation of rocks from the Davie fracture zone (Mozambique Channel) and some tectonic implications. J African Earth Sci (and Middle East) 15: 321-339. https://doi.org/10.1016/0899-5362(92)90018-8

Bassias Y, Leclaire L (1990) The Davie Ridge in the Mozambique Channel: crystalline basement and intraplate magmatism. $\mathrm{N} \mathrm{Jb}$ Geol Paläont Mh H 2:67-90. https://doi.org/10.1127/njgpm/1990/ 1990/67

Bird D (2001) Shear margins: continent-ocean transform and fracture zone boundaries. Lead Edge 20:150-159. https://doi.org/10.1190/ 1.1438894

Bunce ET, Molnar P (1977) Seismic reflection profiling and basement topography in the Somali Basin: Possible fracture zones between Madagascar and Africa. Journal of Geophysical Research 82(33): 5305-5311. https://doi.org/10.1029/JB082i033p05305 
Chorowicz J (2005) The East African rift system. J Afr Earth Sci 43:379410. https://doi.org/10.1016/j.jafrearsci.2005.07.019

Christensen NI, Mooney WD (1995) Seismic velocity structure and composition of the continental crust: a global view. J Geophys Res 100: 9761-9788. https://doi.org/10.1029/95JB00259

Courgeon S, Bachèlery P, Jouet G, Jorry SJ, Bou E, BouDagher-Fadel MK, Révillon S, Camoin G, Poli E (2018) The offshore east African rift system: new insights from the Sakalaves seamounts (Davie Ridge, SW Indian Ocean). Terra Nova 30(5):380-388. https://doi. org/10.1111/ter.12353

Davis JK, Lawver LA, Norton IO, Gahagan LM (2016) New Somali Basin magnetic anomalies and a plate model for the early Indian Ocean. Gondwana Res 34:16-28. https://doi.org/10.1016/j.gr. 2016.02.010

Eagles G, König M (2008) A model of plate kinematics in Gondwana breakup. Geophys J Int 173:703-717. https://doi.org/10.1111/j. 1365-246X.2008.03753.x

Franke D, Jokat W, Ladage S, Stollhofen H, Klimke J, Lutz R, Mahanjane ES, Ehrhardt A, Schreckenberger B (2015) The offshore East African Rift System: structural framework at the toe of a juvenile rift. Tectonics 34:1-19. https://doi.org/10.1002/2015TC003922

Heirtzler JR, Burroughs RH (1971) Madagascar's paleoposition: new data from the Mozambique Channel. Science 174(80):488-490. https://doi.org/10.1126/science.174.4008.488

Jokat W, Boebel T, Koenig M, Meyer U (2003) Timing and geometry of early Gondwana breakup. J Geophys Res 108(B9):2428. https://doi. org/10.1029/2002JB001802

Klimke J, Franke D (2016) Gondwana breakup: no evidence for a Davie Fracture Zone offshore northern Mozambique. Tanzania and Kenya Terra Nov 28:233-244. https://doi.org/10.1111/ter.12214

Klimke J, Franke D, Gaedicke C, Schreckenberger B, Schnabel M, Stollhofen H, Rose J, Chaheire M (2016) How to identify oceanic crust-evidence for a complex break-up in the Mozambique Channel, off East Africa. Tectonophysics 693:436-452. https://doi. org/10.1016/j.tecto.2015.10.012

Klimke J, Franke D, Mahanjane ES, Leitchenkov G (2018) Tie points for Gondwana reconstructions from a structural interpretation of the Mozambique Basin, East Africa and the Riiser-Larsen Sea, Antarctica. Solid Earth 9:25-37. https://doi.org/10.5194/se-9-25-2018

LeClaire L, Bassias Y, Clocchiatti M, Segoufin J (1989) La Ride de Davie dans le Canal de Mozambique: approche startigraphique et géodynamique. C R Acad Sci 308(2):1077-1082

Leinweber VT, Jokat W (2012) The Jurassic history of the AfricaAntarctica corridor - new constraints from magnetic data on the conjugate continental margins. Tectonophysics 530-531:87-101. https://doi.org/10.1016/j.tecto.2011.11.008

Leinweber VT, Klingelhoefer F, Neben S, Reichert C, Aslanian D, Matias L, Heyde I, Schreckenberger B, Jokat W (2013) The crustal structure of the Central Mozambique continental margin - wideangle seismic, gravity and magnetic study in the Mozambique Channel, Eastern Africa. Tectonophysics 599:170-196. https://doi. org/10.1016/j.tecto.2013.04.015

Leitchenkov G, Guseva J, Gandyukhin V, Grikurov G, Kristoffersen Y, Sand M, Golynsky A, Aleshkova N (2008) Crustal structure and tectonic provinces of the Riiser-Larsen Sea area (East Antarctica): results of geophysical studies. Mar Geophys Res 29:135-158. https://doi.org/10.1007/s11001-008-9051-z

Lort JM, Limond WQ, Segoufin J, Patriat P, Delteil JR, Damotte B (1979) New seismic data in the Mozambique Channel. Mar Geophys Res 4:71-89. https://doi.org/10.1007/BF00286146

Mascle J, Mougenot D, Blarez E (1987) African transform continental margins: examples from Guinea, the Ivory Coast and Mozambique. Geol J 22:537-561. https://doi.org/10.1002/gj.3350220632

Mortimer EJ, Gouiza M, Paton DA, Stanca R, Rodriguez K, Hodgson N, Hussein AA, 2020. Architecture of a magma poor passive margin - insights from the Somali margin, Marine Geology,428, https://doi. org/10.1016/j.margeo.2020.106269

Mougenot D, Recq M, Virlogeux P, Lepvrier C (1986) Seaward extension of the East African Rift. Nature 321:599-603. https://doi.org/ $10.1038 / 321599 \mathrm{a} 0$

Müller CO, Jokat W (2017) Geophysical evidence for the crustal variation and distribution of magmatism along the central coast of Mozambique. Tectonophysics 712-713:684-703. https://doi.org/ 10.1016/j.tecto.2017.06.007

Müller CO, Jokat W (2019) The initial Gondwana break-up: a synthesis based on new potential field data of the Africa-Antarctica Corridor. Tectonophysics 750:301-328. https://doi.org/10.1016/j.tecto.2018. 11.008

Müller CO, Jokat W, Schreckenberger B (2016) The crustal structure of Beira High, central Mozambique - combined investigation of wideangle seismic and potential field data. Tectonophysics 683:233-254. https://doi.org/10.1016/j.tecto.2016.06.028

Müller RD, Cannon J, Qin X, Watson RJ, Gurnis M, Williams S, Pfaffelmoser T, Seton M, Russell SHJ, Zahirovic S (2018) GPlates: building a virtual Earth through deep time. Geochem Geophys Geosyst 19:2243-2261. https://doi.org/10.1029/2018GC007584

Ogg JG (2012) Geomagnetic polarity time scale. In: Gradstein FM, Ogg JG, Schmitz M, Ogg G (eds) The Geologic Time Scale 2012. Elsevier, pp 85-113. https://doi.org/10.1016/B978-0-444-59425-9.00005-6

Phethean JJJ, Kalnins LM, van Hunen J, Biffi PG, Davies RJ, McCaffrey KJW (2016) Madagascar's escape from Africa: a high-resolution plate reconstruction for the Western Somali Basin and implications for supercontinent dispersal. Geochem Geophys Geosyst 17:50365055. https://doi.org/10.1002/2016GC006624

Reeves C (2014) The position of Madagascar within Gondwana and its movements during Gondwana dispersal. J Afr Earth Sci 94:45-57. https://doi.org/10.1016/j.jafrearsci.2013.07.011

Reeves CV (2018) The development of the East African margin during Jurassic and Lower Cretaceous times : a perspective from global tectonics. Tectonics and petroleum systems of East Africa 24:4156. https://doi.org/10.1144/petgeo2017-021

Reeves CV, Sahu BK, De Wit M (2002) A re-examination of the paleoposition of Africa's eastern neighbours in Gondwana. J Afr Earth Sci 34:101-108. https://doi.org/10.1016/S0899-5362(02)00011-8

Reeves CV, Teasdale JP, Mahanjane ES (2016) Insight into the Eastern Margin of Africa from a new tectonic model of the Indian Ocean. Geol Soc London Spec Publ 431:299-322. https://doi.org/10.1144/ SP431.12

Sinha ST, Saha S, Longacre M, Basu S, Jha R, Mondal T, 2019. Crustal architecture and nature of continental breakup along a transform margin: new insights from Tanzania-Mozambique Margin. Tectonics 2018TC005221. https://doi.org/10.1029/2018TC005221

Sibuet JC, Klingelhoefer F, Huang YP, Yeh YC, Claude Rangin, Lee CS, Hsu SK (2016) Thinned continental crust intruded by volcanics beneath the northern Bay of Bengal. Marine and Petroleum Geology 77:471-486. https://doi.org/10.1016/j.marpetgeo.2016.07. 006

Stamps DS, Calais E, Saria E, Hartnady C, Nocquet JM, Ebinger CJ, Fernandes RM (2008) A kinematic model for the East African Rift. Geophys Res Lett 35:1-6. https://doi.org/10.1029/ 2007GL032781

Tuck-Martin A, Adam J, Eagles G (2018) New plate kinematic model and tectono-stratigraphic history of the East African and West Madagascan Margins. Basin Res 30:1118-1140. https://doi.org/10. 1111/bre.12294

Virlogeux, P., 1987. Geologie de la marge nord-Mozambique et de la chaine Davie $\left(9^{\circ} \mathrm{S}\right.$ à $\left.21^{\circ} \mathrm{S}\right)$ : campagne MD40-MACAMO, $\mathrm{PhD}$ Thesis. Universite Pierre et Marie Curie.

Vormann, M. and Jokat, W., in review. The crustal structure of the Kerimbas Basin across the offshore branch of the East African Rift system. Geophysical Journal International 
Vormann M, Franke D, Jokat W (2020) The crustal structure of the southern Davie Ridge offshore northern Mozambique - a wideangle seismic and potential field study. Tectonophysics 778 : 228370. https://doi.org/10.1016/j.tecto.2020.228370

White RS, McKenzie D, O'Nions RK (1992) Oceanic crustal thickness from seismic measurements and rare earth element inversions. J Geophys Res 97:19683-19715. https://doi.org/ 10.1029/92JB01749

Publisher's note Springer Nature remains neutral with regard to jurisdictional claims in published maps and institutional affiliations. 